Jurnal Ilmu Sosial dan Pendidikan (JISIP)

Vol. 6, No. 1 Januari 2022

e-ISSN : 2656-6753, p-ISSN: 2598-9944

DOI: 10.36312/jisip.v6i1.2733/http://ejournal.mandalanursa.org/index.php/JISIP/index

\title{
Implementasi Program Sembako Di Kecamatan Kawangkoan Utara Kabupaten Minahasa
}

\author{
Felini O. Toporundeng ${ }^{1}$, Wilson Bogar ${ }^{2}$, Fitri H. Mamonto ${ }^{3}$ \\ ${ }^{1,2,3}$ Program Studi Administrasi Negara Program Pascasarjana Universitas Negeri Manado
}

\begin{tabular}{l}
\hline \hline Article Info \\
\hline Article history: \\
Received 22 Desember 2021 \\
Publish 04 Januari 2022
\end{tabular}

Publish 04 Januari 2022

\section{Keywords:}

Implementasi

Kebijakan

Program Sembako

Minahasa \begin{abstract}
ABSTRAK
. Penelitian ini bertujuan untuk mengetahui, mendeskripsikan dan menganalisis mekanisme pelaksanaan Program Sembako di Kecamatan Kawangkoan Utara Kabupaten Minahasa. Metode penelitian yang digunakan yakni kualitatif. Hasil penelitian menunjukkan bahwa: 1) Pengetahuan aparat pemerintah tentang proses persiapan pelaksanaan, landasan regulasi, pedoman umum, bahkan Program BPNT yang bertransformasi menjadi Program Sembako masih sangat minim. 2) Edukasi dan sosialisasi sudah diberikan kepada masyarakat dan KPM Program Sembako tetapi masih kurangnya pengetahuan aparat pemerintah terkait alur dan pelaksana edukasi dan sosialisasi Program Sembako. 3) Tidak adanya pendampingan dari pemerintah desa saat pendistribusian KKS, kemudian kurangnya pemahaman secara spesifik tentang tahapan pelaksanaan pendistribusian KKS dan penyebutan Kartu Keluarga Sejahtera (KKS) oleh Pimpinan Kecamatan dan KPM. 4) KPM Program Sembako masih belum tepat sasaran kemudian belum ada pemutakhiran data terkait KPM Program Sembako, dan Pemerintah Desa yang masih belum mengetahui secara terperinci kriteria KPM yang dapat diganti. 5) Proses penyaluran dana bantuan program Sembako masih kurangnya dipahami oleh para implementor dan adanya keterlambatan penyaluran dana bantuan, dan ada KPM yang tidak berada ditempat saat penyaluran bantuan. Adapun faktor-faktor determinan dalam penelitian ini adal ah komunikasi, sumber daya, disposisi (sikap), dan struktur birokrasi
\end{abstract}

This is an open access article under the Lisensi Creative Commons AtribusiBerbagiSerupa 4.0 Internasional

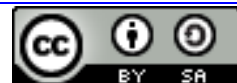

\section{Corresponding Author:}

Felini O. Toporundeng

Universitas Negeri Manado

Email : feliniot@gmail.com

\section{PENDAHULUAN}

Pemerintah Indonesia membuat berbagai kebijakan dan program bantuan dalam rangka menanggulangi kemiskinan dan untuk memenuhi kebutuhan dasar setiap warga negara pemerintah memberikan berbagai bantuan sosial kepada masyarakat baik itu berupa uang, barang, atau jasa kepada seseorang, keluarga, kelompok atau masyarakat miskin, tidak mampu, dan rentan terhadap risiko sosial agar tetap hidup secara wajar.

Dalam Peraturan Menteri Sosial Nomor 5 Tahun 2021 tentang Pelaksanaan Program Sembako dalam pasal 1 poin 5 menjelaskan bahwa Program Sembako adalah program Bantuan Sosial pangan yang merupakan pengembangan dari program BPNT dengan perubahan nilai bantuan dan jenis bahan pangan.

Program Sembako memastikan program menjadi lebih tepat sasaran, tepat jumlah, tepat waktu, tepat harga, tepat kualitas, dan tepat administrasi dan bantuan sosial yang disalurkan secara nontunai dari pemeintah yang diberikan kepada KPM setiap bulannya melalui uang elektronik selanjutnya digunakan untuk membeli bahan pangan yang telah ditentukan di ewarung. Program Sembako diharapkan dapat memberikan pilihan kepada penerima manfaat dalam memilih jenis, kualitas, harga dan tempat membeli bahan pangan. Program Sembako diberikan melalui Kartu Keluarga Sejahtera (KKS) yang memiliki fitur yang memiliki fitur uang 
elektronik dan/atau tabungan serta dapat digunakan sebagai media penyaluran bantuan social. (Pedoman Program Sembako, 2020)

Adapun yang menjadi mekanisme pelaksanaan Program Sembako berdasarkan buku Pedoman Program Sembako tahun 2020 dan regulasi yang ada yakni meliputi: 1) Persiapan; 2) Edukasi dan Sosialisasi 3) Registrasi dan Distribusi KKS; 4) Penggantian KPM; 5) Penyaluran Dana Bantuan; dan 6) Pemanfaatan Dana Bantuan.

Berdasarkan penelitian yang telah dilakukan oleh peneliti untuk implementasi Program Sembako di Kecamatan Kawangkoan Utara Kabupaten Minahasa, terdapat permasalahan yang terjadi yakni ada beberapa aparat pemerintah yang masih belum mengetahui bahwa Program Sembako ini merupakan pengembangan dari program BPNT, atau yang sekarang sudah bertransformasi menjadi Program Sembako, bahkan usulan nama-nama KPM yang ditambah hanya diusulkan secara intern oleh pemerintah desa tidak lewat musdes, kemudian ada KPM yang saat waktu penerimaan bantuan tidak ada ditempat, selanjutnya adanya keterlambatan penyaluran dana bantuan Program Sembako sampai 3 (tiga) bulan kepada KPM, dan masih belum tepatnya sasaran KPM Program Sembako di Kecamatan Kawangkoan Utara, sedangkan masih ada keluarga atau masyarakat yang lebih layak dan memenuhi syarat sebagai penerima Program Sembako/BPNT, dan juga dalam segi ekonomi tergolong ekonomi rendah atau miskin tetapi belum menjadi anggota KPM Program Sembako/BPNT. Dampaknya tujuan Program Sembako belum bisa tercapai secara optimal bahkan manfaat program ini masih belum bisa dirasakan secara signifikan oleh seluruh masyarakat miskin yang ada di Kecamatan Kawangkoan Utara karena masih adanya beberapa temuan masalah dari hasil penelitian yang telah peneliti lakukan.

\section{METODE PENELITIAN}

Metode yang digunakan dalam penelitian ini yaitu metode penelitian kualitatif. Metode ini peneliti anggap baik dan dapat membantu peneliti dalam mendeskripsikan dan menganalisis permasalahan tentang Implementasi Program Sembako di Kecamatan Kawangkoan Utara Kabupaten Minahasa.

Adapun fokus penelitiannya ialah pada fokus I yakni Implementasi Program Sembako dilihat dari Mekanisme Pelaksanaan di Kecamatan Kawangkoan Utara Kabupaten Minahasa, subfokusnya yaitu 1) Persiapan, 2) Edukasi dan Sosialisasi, 3) Registrasi dan Distribusi KKS, 4) Penggantian KPM, 5) Penyaluran Dana Bantuan. Kemudian pada fokus II terkait faktorfaktor determinan pada Implementasi Program Sembako di Kawangkoan Utara Kabupaten Minahasa diantaranya ada faktor komunikasi, sumber daya, disposisi (sikap), dan struktur birokrasi.

Instrument penelitian yang utama adalah peneliti itu sendiri. Sumber Data yakni informan dengan 6 orang informan, tempat dan peristiwa di Kecamatan Kawangkoan Utara Kabupaten Minahasa, dokumen yakni Peraturan Menteri Sosial Nomor 5 Tahun 2021 tentang Pelaksanaan Program Sembako, dan Buku Pedoman Umum Program Sembako Tahun 2020.

Teknik pengumpulan data yakni sebagai berikut: 1) Proses memasuki lokasi penelitian (Getting in); 2) Ketika berada di lokasi penelitian (Getting along); 3) Mengumpulkan data (Loging the data). Teknis Analisis Data meliputi Reduksi Data, Penyajian data, dan Verifikasi Data.

\section{HASIL PENELITIAN DAN PEMBAHASAN}

\subsection{Hasil Penelitian}

\section{Implementasi Program Sembako dilihat dari Mekanisme Pelaksanaan di Kecamatan Kawangkoan Utara Kabupaten Minahasa}

Kebijakan publik adalah suatu rangkaian yang menjadi pilihan tentang apa yang dilakukan dan tidak dilakukan oleh pemerintah baik itu berupa program-program dalam rangka mencapai tujuan yang telah ditetapkan dan terkait hal ini pemerintah Indonesia melalui Peraturan Presiden Republik Indonesia Nomor 5 Tahun 2021 tentang Pelaksanaan Program 
Sembako. Implementasi kebijakan menurut Nugroho (2011:618) adalah cara agar sebuah kebijakan dapat mencapai tujuan, yang mengimplementasikan dalam bentuk program atau turunan dari kebijakan publik. Kebijakan publik dalam bentuk undang-undang memerlukan pedoman umum atau pedoman pelaksana.

Mekanisme pelaksanaan Program Sembako berdasarkan buku Pedoman Program Sembako tahun 2020 dan regulasi yang ada yakni: 1) Persiapan; 2) Edukasi dan Sosialisasi, 3) Registrasi dan Distribusi KKS, 4) Penggantian KPM, 5) Penyaluran Dana Bantuan, dan 6)

Pemanfaatan Dana Bantuan. Dari mekanisme tersebut peneliti dan deskripsi data hasil penelitian maka pembahasan akan diuraikan kedalam 5 (lima) subfokus pada Fokus I dalam penelitian ini yakni sebagai berikut:

\section{a. Persiapan}

Persiapan merupakan tahap awal kegiatan setelah Kementerian Sosial menetapkan pagu program Sembako, Wilayah kabupaten/kota dan mekanisme pelaksanaan, serta Bank Penyalur. Sedangkan menurut Kamus Besar Bahasa Indonesia persiapan ialah 1) perlengkapan dan persediaan (untuk sesuatu), 2) perbuatan (hal dsb) bersiap-siap atau mempersiapkan; tindakan (rancangan dsb) untuk sesuatu. Kegiatan ini meliputi koordinasi pelaksanaan, penyiapan data KPM, pembukaan rekening kolektif dan penyiapan eWarong. Selanjutnya menurut Lester dan Stewart (Kusumanegara, 2010:97) mengemukakan bahwa implementasi kebijakan publik adalah tahapan yang dilakukan setelah aturan hukum ditetapkan melalui proses politik.

Berdasarkan teori tersebut jika dikaitkan dengan hasil wawancara yang telah peneliti lakukan peneliti mendapati ada beberapa temuan yang muncul yakni mulai dari pengetahuan terkait proses persiapan pelaksanaan Program Sembako oleh Pemerintah Kecamatan hanya terbatas pada penetapan KPM lewat Musdes, ada aparat pemerintah desa yang tidak mendapatkan informasi terkait daftar KPM Program Sembako, kemudian implementor dan KPM Program Sembako sama sekali belum mengetahui apalagi memahami secara spesifik landasan regulasi dan pedoman Program Sembako, bahkan belum ada pembagian buku pedoman Program Sembako kepada pemerintah desa oleh Pendamping program bantuan, dan ada sikap tidak ingin tau terkait Pedoman Program Sembako yang ditunjukan oleh pimpinan Kecamatan, dan juga Perangkat Desa memang masih belum mengetahui dan memahami terkait Program BPNT yang bertransformasi menjadi Program Sembako. Kebijakan harus dapat dilaksanakan secara baik dan sesuai dengan landasan yang ada agar pencapaian tujuan dapat terlaksana dengan baik dan optimal, bahkan salah satu tujuan untuk mensejahterakan masyarakat dapat terus berjalan secara maksimal.

\section{b. Edukasi dan Sosialisasi}

Edukasi dan sosialisasi program Sembako mempunyai tujuan 1) Memberikan pemahaman kepada para pemangku kepentingan di pusat dan daerah mengenai kebijakan dan aspek pelaksanaan program Sembako, khususnya terkait keberadaan program Sembako sebagai pengembangan dari program BPNT. 2)Memberikan pemahaman kepada KPM tentang tujuan dan mekanisme pemanfaatan dana bantuan program Sembako. 3) Memberikan informasi tentang mekanisme pengaduan program Sembako. 4) Memberikan pemahaman kepada KPM tentang pentingnya pemenuhan gizi pada 1000 Hari Pertama Kehidupan (HPK) untuk mencegah stunting melalui pemanfaatan bantuan program Sembako.

Dye dalam Hakim (2011:114) mengemukakan bahwa kebijakan publik adalah apa saja yang dilakukan dan tidak dilakukan oleh pemerintah. Dalam hal ini kebijakan merupakan upaya untuk memahami dan mengartikan apa yang dilakukan atau tidak dilakukan oleh pemerintah mengenai suatu masalah publik.

Dari teori tersebut jika dikaitkan dengan hasil penelitian yang telah peneliti dapatkan dan telah diuraikan ke deskripsi hasil penelitian maka edukasi dan sosialisasi sudah ada yang diberikan kepada masyarakat dan KPM Program Sembako, kemudian 
masih kurangnya pengetahuan aparat pemerintah terkait pelaksana sosialisasi Program Sembako karena para informan hanya sebatas mengetahui pelaksana program Sembako hanya dari pemerintah saja, selanjutnya Pemerintah Kecamatan dan Desa masih kurang paham terkait alur edukasi dan sosialisasi yang ada, dan Sosialisasi dan edukasi yang diberikan sekarang hanya melalui pesan di Grup Whatsapp sehingga ada kesengjangan antara harapan dan kenyataan seharusnya sebagai implementor program harus betul-betul proaktif terkait informasi terbaru dari Program Sembako, agar tujuan negara yang telah ditetapkan oleh pemerintah yang tercamtun dalam Alinea ke-4 Pembukaan UndangUndang Dasar 1945 dan tujuan program Sembako bisa tercapai secara optimal.

\section{c. Registrasi dan Distribusi KKS}

Proses registrasi atau distribusi KKS untuk pelaksanaan program Sembako dilaksanakan bagi KPM yang baru ditetapkan sebagai penerima program Bansos Pangan di tahun 2020. KKS yang telah dimiliki KPM dari program BPNT dan atau PKH tetap digunakan untuk mendapatkan dan memanfaatkan dana bantuan program Sembako. kemudian Laswell dan Kaplan dalam Nugroho (2011:93-94) mengatakan bahwa kebijakan publik adalah suatu program yang diproyeksikan dengan tujuan, nilai-nilai dan praktikpraktik tertentu.

Dari hasil penelitian dikaitkan dengan teori peneliti menemukan bahwa tidak adanya pendampingan dari pemerintah desa saat pendistribusian KKS , kemudian KPM yang kurang mengetahui penyebutan kartu yang digunakan dalam program Sembako itu disebut KKS, dan proses pelaksana pendistribusian KKS hanya dilaksanakan oleh Pendamping Bantuan Program, bahkan pimpinan dan KPM masih kurang memahami secara spesifik tahapan pelaksanaan pendistribusian KKS kepada KPM. Mereka hanya sebatas mengetahui bahwa prosesnya hanya melalui pemberitahuan oleh pendamping kepada KPM yang dikumpulkan disatu tempat, setelah itu baru dibagikan KKS kepada penerima manfaat program bantuan ini, sedangkan sudah dijelaskan secara detail dan disimpulkan secara jelas dalam buku pedoman sesuai dengan teori yang telah peneliti uraikan sebelumnya.

\section{d. Penggantian KPM}

Penggantian KPM dapat dilakukan sepanjang terjadi perubahan data, hal tersebut sesuai dengan yang dijelaskan dalam Permensos Nomor 5 Tahun 2021 pasal 30 ayat 1. Ayat 2 menjelaskan penggantian KPM sebagaimana dimaksud dilakukan karena KPM: a) pindah alamat; b) tidak ditemukan di alamat; c)meninggal dunia; d) sudah mampu secara ekonomi; e) menolak menerima bantuan; f) memiliki kepesertaan ganda; atau g) menjadi pekerja migran Indonesia sebelum melakukan aktivasi KKS.

Menurut Nugroho (2011:650) menjelaskan ada lima (5) prinsip-prinsip pokok dalam implementasi kebijakan publik, salah satunya yaitu tepat target artinya ketepatan berkenaan dengan tiga hal. 1) apakah target yang diintervensi sesuai dengan yang direncanakan, apakah tidak ada tumpang tindih dengan intervensi lain, atau tidak bertentangan dengan intervensi kebijakan lain. 2) apakah targetnya dalam kondisi siap untuk diintervensi atau tidak. 3) apakah intervensi implementasi kebijakan bersifat baru atau memperbaharui implementasi kebijakan sebelumnya.

Berdasarkan hasil temuan yang dipaparkan dalam tabel temuan jika dikaitkan dengan teori diatas dapat dijelaskan bahwa masih banyak masyarakat yang berada ditingkat ekonomi rendah tetapi tidak dimasukkan dalam daftar KPM Program Sembako, kemudian belum adanya pemutakhiran data terkait KPM Program Sembako, ada sikap dari Pimpinan kecamatan yang menganggap 14 syarat kemiskinan itu tidak terlalu dibutuhkan dalam penetapan KPM, belum tepatnya sasaran KPM Program Sembako sehingga tidak sesuai dengan teori dari Nugroho yang menjelaskan kebijakan harus tepat target, dan usulan nama-nama yang ditambah ternyata hanya diusulkan secara intern oleh pemerintah desa tidak lewat musdes, sedangkan dalam aturan sudah disebutkan haru dilaksanakan lewat musdes atau muscam, bahkan Pemerintah Desa yang masih belum 
mengetahui secara terperinci kriteria KPM yang dapat diganti atau dikeluarkan dan proses pelaksanaannya, kebanyakan informan hanya memahami KPM yang dapat diganti hanya yang sudah meninggal saja.

e. Penyaluran Dana Bantuan

Proses penyaluran dana bantuan program Sembako menurut Pedoman Program Sembako (2020) dilaksanakan sebagai berikut: 1) Proses penyaluran dana bantuan program Sembako dilaksanakan oleh Bank Penyalur tanpa pengenaan biaya; 2) Proses penyaluran dilakukan dengan memindahbukukan dana bantuan program Sembako dari rekening Kementerian Sosial (KPA) di Bank Penyalur ke rekening bantuan pangan/subakun uang elektronik KPM. 3) Pemindahbukuan dana bantuan program Sembako ke rekening/sub-akun elektronik KPM dilakukan paling lama 30 hari kalender sejak dana tersebut ditransfer dari Kas Negara ke rekening Kementerian Sosial di Bank Penyalur. 4) Penyaluran dana bantuan program Sembako ke dalam rekening bantuan pangan/sub-akun uang elektronik KPM dilakukan setiap bulan, paling lambat tanggal 10 (sepuluh) bulan berjalan; 5) Proses penyaluran dana bantuan program Sembako dilakukan sesuai dengan ketentuan peraturan perundang-undangan mengenai Belanja Bansos yang ditetapkan oleh Menteri yang menyelenggarakan urusan pemerintahan di bidang keuangan.

Menurut Dunn (2003:35) kebijakan publik adalah suatu rangkaian pilihan-pilihan yang saling berhubungan yang dibuat oleh lembaga atau pejabat pemerintah pada bidangbidang yang menyangkut tugas pemerintahan, seperti pertahanan keamanan, energi, kesehatan, pendidikan, kesejahteraan masyarakat, kriminaitas, perkotaan dan lain-lain. Jadi, sudah pasti program Sembako ini berkaitan dengan peningkatan kesejahteraan masyarakat sejalan juga dengan tujuan negara.

Berdasarkan hasil penelitian yang dikaitkan dengan teori didapati bahwa masih kurangnya pemahaman terkait proses penyaluran dana bantuan program Sembako oleh para Implementor, bahkan para implementor yang belum mengetahui secara tepat pelaksana penyaluran dana bantuan Program Sembako, dan ada KPM yang saat waktu penerimaan bantuan tidak ada ditempat, kemudian implementor dan KPM Program Sembako yang masih belum mengetahui bahwa dana bantuan dapat dibelanjakan di ewarung yang lain, padahal dalam regulasi dan pedoman sudah dijelaskan secara jelas. Jadi bisa dilihat ada kesenjangan antara kebijakan dan kenyataan dari hasil temuan yang didapat.

\subsection{Pembahasan}

\section{Faktor-faktor Determinan pada Implementasi Program Sembako di Kecamatan Kawangkoan Utara Kabupaten Minahasa}

Ada begitu banyak faktor yang menghambat dan mendukung proses implementasi kebijakan dan faktor utama adalah implementor kebijakan dilapangan yang paling menentukan apakah kebijakan dapat terlaksana dengan baik atau tidak.

Berdasarkan uraian diatas dapat dipahami bahwa keberhasilan implementasi kebijakan sangat dipengaruhi oleh berbagai variabel atau faktor yang pada gilirannya akan mempengaruhi keberhasilan implementasi kebijakan itu sendiri. Jadi, bisa dikatakan bahwa hal tersebut sangat penting untuk menentukan apakah kebijakan tersebut dapat berhasil atau tidak. Berikut ini faktor-faktor determinan yang ada pada Implementasi Program Sembako di Kecamatan Kawangkoan Utara Kabupaten Minahasa.

\section{a. Komunikasi}

Komunikasi menurut Edwards III berkaitan dengan implementasi kebijakan publik yang agar dapat mencapai keberhasilan, mensyaratkan agar implementor mengetahui apa yang harus dilakukan secara jelas. Apa yang menjadi tujuan dan sasaran kebijakan harus diinformasikan kepada kelompok sasaran (target group) sehingga akan mengurangi distorsi implementasi. Sedangkan komunikasi antar badan pelaksana menurut Van Meter dan Van Horn (dalam Nugroho 2011:628) menunjuk kepada mekanisme prosedur yang dicanangkan untuk mencapai sasaran dan tujuan progam. 
Teori tersebut dapat disimpulkan dan dipahami bahwa komunikasi menjadi salah sau faktor yang sangat penting dalam penentuan keberhasilan implementasi kebijakan publik bahwa setiap implementor harus berkoordinasi secara baik, mengetahui secara spesifik tentang aturan yang ditetapkan dan harus sering melakukan sosialisasi kepada kelompok sasaran untuk mencapai tujuan yang ditelah ditetapkan.

Berdasarkan teori tersebut jika dikaitkan dengan hasil penelitian yang ada didapati bahwa koordinasi antara pemerintah kecamatan dan pendamping Program Sembako sudah berjalan dengan baik, kemudian pemerintah desa belum dilibatkan dalam pelaksanaan evaluasi, sehingga peneliti menganalisis dan mengambil kesimpulan bahwa evaluasi yang dilakukan hanya melibatkan KPM dan Pemerintah Kecamatan tetapi untuk pemerintah desa masih belum dilibatkan oleh pendamping. Selanjutnya masih adanya penolakan dari masyarakat terkait KPM program Sembako kepada Pemerintah Kecamatan, karena adanya keluhan terkait KPM program bansos pangan ini yang seharusnya sudah bisa diganti tetapi belum ada pemutakhiran data yang dilaksanakan sampai sekarang, pemutakhiran yang dilaksanakan sampai sekarang ternyata hanya KPM yang sudah meninggal ataupun berpindah tempat.

\section{b. Sumber Daya}

Menurut Makmur dan Thahier (2016:351) sumber daya memiliki beraneka ragam jenis, bentuk, dan jumlahnya, tetapi kalau kita memodifikasi dari sekian banyak jenis, bentuk, dan jumlahnya sumber daya yang dimiliki organisasi publik, sesungguhnya dapat digolongkan secara garis berasnya menjadi dua golongan, yaitu yang pertama sumber daya yang berasal dari manusia dengan diistilahkan (human resources) yang memiliki jenis kelemahan dan jenis kekuatan yang berbeda antara manusia yang satu dengan manusia yang lainnya, dan yang kedua sumber daya yang bukan manusia diistilahkan (non human resources) yang juga memiliki bentuk dan jenis yang sangat beragam. Kemudian Mazmanian dan Sabatier menjelaskan bahwa aspek dependen yakni aspek di luar kebijakan yang mempengaruhi proses implementasi kebijakan. Cakupannya adalah: 1) kondisi sosial ekonomi dan teknologi, 2) dukungan publik, 3) sikap dan sumber daya yang dimiliki kelompok, 4) dukungan dari pejabat atasan.

Sesuai dari teori tersebut peneliti memahami bahwa sumber daya memiliki keberagaman jenis dan bentuk terbagi dalam sumber daya manusia dan bukan manusia yakni dalam bentuk uang, bahan pangan, dan dokumen yang berpotensi memberikan kekuatan ataupun kelemahan pada suatu pelaksanaan program.

Jika hasil temuan penelitian dikaitkan dengan teori tersebut didapati bahwa adanya ketidaktahuan para implementor terkait jumlah KPM Program Sembako di kecamatan Kawangkoan Utara, dan pemerintah desa yang masih belum mengetahui secara pasti jumlah dana bantuan yang diterima setiap bulan oleh KPM Program Sembako, kemudian ada penambahan jumlah dana bantuan yang diterima dari Rp. 150.000 menjadi Rp. 200.000 perbulan, selanjutnya dana bantuan yang diterima oleh KPM ternyata sudah cukup untuk membantu kebutuhan pangan setiap bulan.

c. Disposisi (Sikap)

Van Meter dan Van Horn (dalam Nugroho 2011:628) menjelaskan bahwa sikap pelaksana menjadi variabel atau faktor penting dalam implementasi kebijakan. Sehingga dapat dilihat model ini menunjukkan bahwa implementasi kebijakan merupakan model yang sangat kompleks, dimana satu faktor atau variabel dapat mempengaruhi faktor yang lain.

Dari teori tersebut peneliti bisa menjelaskan bahwa tindakan atau karakter para implementor kebijakan sangat mempengaruhi tingkat keberhasilan implementasi kebijakan, kemudian sikap merupakan salah satu faktor yang mempengaruhi tingkat keberhasilan suatu kebijakan dan tindakan yang dilakukan para implementor harus benar-benar terarah, mempunyai etika, dan jujur yang sesuai dengan kebijakan sehingga tidak menyimpang dari petunjuk teknis. 
Berdasarkan hasil penelitian yang telah peneliti lakukan jika dikaitkan dengan teori tersebut ditemukan bahwa sikap pemerintah dan pedamping program dalam menyampaikan bantuan kepada masyarakat sudah disampaikan secara baik, tetapi adanya keterlambatan penyaluran dana bantuan Program Sembako sampai 3 (tiga) bulan kepada KPM, kemudian pemerintah dan pendamping sudah menyediakan sistem informasi yang transparan kepada masyarakat dalam bentuk pelaporan dan evaluasi, tetapi ternyata kadangkala pelaporan dan evaluasi yang ada hanya disampaikan secara intern kepada pemerintah kecamatan, sehingga bisa dikatakan bahwa belum semua informasi yang terkait program Sembako disampaikan kepada masyarakat, maka belum bisa dikatakan transparan karena masih ada hal-hal yang hanya disampaikan secara intern oleh pendamping atau pemerintah desa seperti penggantian data KPM.

\section{d. Struktur Birokrasi}

Struktur birokrasi menurut Edward III berkenaan dengan kesesuaian organisasi birokrasi yang menjadi penyelenggara implementasi kebijakan publik. Kemudian organisasi menyediakan peta sederhana untuk menunjukkan secara umum kegiatankegiatannya dan jarak dari puncak menunjukkan status relatifnya.

Menurut Gow dan Morss (Pasolong, 2007:59) menyebutkan berbagai hambatan dalam implementasi kebijakan antara lain (1) hambatan politik, ekonomi dan lingkungan, (2) kelemahan intitusi, (3) ketidakmampuan SDM dibidang teknis dan administratif, (4) kekurangan bantuan teknis, (5) kurangnya desentralisasi dan partisipasi, (6) pengaturan waktu, (7) sistem informasi yang kurang mendukung, (8) perbedaan agenda tujuan antara aktor (dukungan yang berkesinambungan).

Berdasarkan teori tersebut peneliti menyimpulkan bahwa struktur birokrasi merupakan suatu tatanan organisasi, bagan ataupun pembagian kerja secara hierarki yang tedapat pada suatu lembaga ataupun organisasi pemerintahan dalam rangka untuk menjalankan tugas-tugas agar lebih terarah, teratur bahkan dapat dikelola dengan baik.

Dari teori diatas jika peneliti mengaitkan dengan hasil penelitian yang ada maka ada beberapa temuan yang muncul yaitu pemerintah desa masih belum aktif mengawasi saat kegiatan penyaluran bantuan program Sembako kepada para penerima manfaat, sehingga hal tersebut masih belum sesuai dengan kebijakan yang telah ditetapkan oleh pemerintah pusat yang menjelaskan bahwa dalam penyaluran atau kegiatan program Sembako ini harus ada pengawasan yang diberikan oleh pemerintah desa saat pelaksanaan penyaluran bantuan Program Sembako kepada para KPM. Tetapi ada juga faktor penunjangnya yakni prosedur yang ada pada saat pelaksanaan penyaluran Program Sembako sudah sangat dimudahkan.

\section{KESIMPULAN}

\section{a. Implementasi Program Sembako dilihat dari Mekanisme Pelaksanaan di Kecamatan} Kawangkoan Utara Kabupaten Minahasa

Berdasarkan deskripsi hasil penelitian dan pembahasan terkait Implementasi Program Sembako dilihat dari mekanisme pelaksanaan, maka kesimpulan yang peneliti ambil dari hasil penelitian yang sudah dipaparkan dan dianalisis pada bab sebelumnya, ialah sebagai berikut:

1) Pengetahuan aparat pemerintah tentang proses persiapan pelaksanaan, landasan regulasi, pedoman umum, bahkan Program BPNT yang bertransformasi menjadi Program Sembako masih sangat minim.

2) Edukasi dan sosialisasi sudah diberikan kepada masyarakat dan KPM Program Sembako tetapi masih kurangnya pengetahuan aparat pemerintah terkait alur dan pelaksana edukasi dan sosialisasi Program Sembako.

3) Tidak adanya pendampingan dari pemerintah desa saat pendistribusian KKS, kemudian kurangnya pemahaman secara spesifik tentang tahapan pelaksanaan pendistribusian 
KKS dan penyebutan Kartu Keluarga Sejahtera (KKS) oleh Pimpinan Kecamatan dan KPM.

4) KPM Program Sembako masih belum tepat sasaran kemudian belum ada pemutakhiran data terkait KPM Program Sembako, dan Pemerintah Desa yang masih belum mengetahui secara terperinci kriteria KPM yang dapat diganti.

5) Proses penyaluran dana bantuan program Sembako masih kurangnya dipahami oleh para implementor, dan ada KPM yang tidak berada ditempat saat penyaluran bantuan.

b. Faktor-faktor Determinan pada Implementasi Program Sembako di Kecamatan Kawangkoan Utara Kabupaten Minahasa

Berdasarkan hasil data penelitian dan pembahasan seperti yang telah dianalisis dan diuraikan pada bab sebelumnya. Maka peneliti bisa mengambil kesimpulan bahwa faktorfaktor determinan yang ada pada Implementasi Program Sembako, yaitu:

1) Komunikasi: Koordinasi antara pemerintah kecamatan dan pendamping Program Sembako sudah berjalan dengan baik, tetapi pemerintah desa belum dilibatkan dalam pelaksanaan evaluasi dan adanya penolakan dari masyarakat terkait KPM program Sembako kepada Pemerintah Kecamatan.

2) Sumber Daya: Adanya ketidaktahuan para implementor terkait jumlah KPM dan besaran dana bantuan pada Program Sembako di kecamatan Kawangkoan Utara, kemudian ada penambahan jumlah dana bantuan yang diterima dari Rp. 150.000 menjadi Rp. 200.000 perbulan.

3) Disposisi (Sikap): Sikap pemerintah dan pedamping program dalam menyampaikan bantuan kepada masyarakat sudah disampaikan secara baik, tetapi masih adanya keterlambatan penyaluran dana bantuan Program Sembako sampai 3 (tiga) bulan kepada KPM.

4) Struktur Birokrasi: Pemerintah desa masih belum aktif mengawasi kegiatan penyaluran bantuan program Sembako kepada para penerima manfaat, prosedur yang ada saat pelaksanaan penyaluran Program Sembako kepada KPM sudah sangat dimudahkan dan Pendamping Program Sembako aktif turun kelokasi.

\section{DAFTAR PUSTAKA}

Buku Pedoman Umum Program Sembako Tahun 2020.

Dunn, William N. 2003. Analisis Kebijakan Publik. Yogyakarta: Gadjah Mada University Press. Hakim, Lukman. 2011. Pengantar Administrasi Pembangunan. Yogyakarta: Ar-Ruzz Media.

Kusumanegara, Solahuddin. 2010. Model dan Aktor Dalam Proses Kebijakan Publik. Yogyakarta: Gava Media.

Makmur \& Thahier, Rohana. 2016. Konseptual dan Kontekstual Administrasi dan Organisasi

Terhadap Kebijakan Pubik. Bandung: PT Refika Aditama.

Nugroho, Riant. 2011. Public Policy. Jakarta: PT Elex Media Komputindo.

Pasolong, Harbani. 2007. Teori Administrasi Publik. Bandung: Alfabeta.

Peraturan Menteri Sosial Republik Indonesia Nomor 5 Tahun 2021 tentang Pelaksanaan Program Sembako. 